\title{
Agronomic Performance of Modern Rice Varieties in South- west Bangladesh
}

\author{
Md. Tareq Bin Salam ${ }^{1}$, Biswajit Karmakar ${ }^{2}$, S.M. Tanzim Hossain ${ }^{1}$, Mehedi Hasan Robin ${ }^{1}$, Most. \\ Zannatul Mariam $^{1} \&$ Mehjabin Hossain ${ }^{1}$
}

${ }^{1}$ Soil, Water and Environment Discipline, Khulna University, Khulna 9208, Bangladesh

${ }^{2}$ Bangladesh Rice Research Institute, Joydebpur, Gazipur 1701, Bangladesh

\section{Article history}

Received: 04 September 2019 Accepted: 02 October 2019

Published: 27 October 2019

\section{Publisher}

Horizon e-Publishing Group

\section{* Correspondence}

Md. Tareq Bin Salam

$凶$ tareqss ku@rocketmail.com

\begin{abstract}
An experiment was carried out in Boro season during November 2018 to April 2019 at two farmer's fields of Batiaghata and Dumuria sub-district under Khulna district of Bangladesh with the objective of testing agronomic status and adaptability of four modern rice varieties in comparison with the popular mega variety BRRI dhan28. The varieties were BRRI dhan67, BRRI dhan81, BRRI dhan84 and BRRI dhan86. BRRI dhan28 was chosen as a control due to its wide acceptability among the farmers. The soil of the studied area was moderately alkaline and medium to moderately saline. In Batiaghata and Dumuria field, initial soil EC was 3.19 and $3.29 \mathrm{dS} / \mathrm{m}$, respectively and it was 4.7 and $4.8 \mathrm{dS} / \mathrm{m}$, accordingly at maturity stage. It was observed that germination rate, plant height, effective tiller number were significantly higher in BRRI dhan67 than the other varieties but insignificant with BRRI dhan28 $(p \leq 0.05)$ for both fields. All the yield components spikelets per panicle, filled grain and 1000-grain weight were also significantly higher in BRRI dhan67 in compared to the other varieties but insignificant with BRRI dhan28 $(p \leq 0.05)$ for both fields as well. The highest grain yield was observed in BRRI dhan67 in both plots (7.89 and 7.29 t/ha) and showed significant differences among all other varieties $(p \leq 0.05)$. Harvest Index of BRRI dhan67 $(51.02 \pm 4.2,57.84 \pm 8.6) \%$ indicated that this variety is the best yielder among the varieties. Considering overall performances and facts, BRRI dhan67 showed better agronomic performance and adaptation than the other modern varieties in compare with popular mega BRRI dhan28.
\end{abstract}

Keywords: Boro (dry season) rice; soil salinity; germination; grain yield; harvest Index.

Citation: Salam T B, Karmakar B, Hossain S M T, Robin M H, Mariam M Z, Hossain M. Agronomic Performance of Modern Rice Varieties in South-west Bangladesh. Plant Science Today 2019;6(4):528-532. https://doi.org/10.14719/pst.2019.6.4.632

Copyright: (C) Salam et. al. (2019). This is an open-access article distributed under the terms of the Creative Commons Attribution License, which permits unrestricted use, distribution, and reproduction in any medium, provided the original author and source are credited (https://creativecommons.org/licenses/by/4.0/).

Indexing: Plant Science Today is covered by Scopus, Web of Science, BIOSIS Previews, ESCI, CAS, AGRIS, CABI, UGC-CARE, Google Scholar, etc. Full list at http://www.plantsciencetoday.online

\section{Introduction}

Rice is the main source of food for people of Bangladesh and staple food almost half of the world's population. The dominant food crop of Bangladesh is rice covering about $75 \%$ of agricultural land and contributing $28 \%$ of GDP (1).
Bangladesh is very vulnerable about the impact of climate change. Due to climatic change effects, salinity is increasing day by day, decreasing pest controlling capability, and increasing new pest invasion in the south-western part of Bangladesh. Out of 2.86 million hectares of coastal and offshore 
Table 2. Seed germination rate and plant height of rice varieties at different stages

\begin{tabular}{|c|c|c|c|c|c|c|c|c|}
\hline \multirow{3}{*}{ Rice Variety } & \multirow{2}{*}{\multicolumn{2}{|c|}{$\begin{array}{c}\text { Seed germination } \\
(\%)\end{array}$}} & \multicolumn{6}{|c|}{ Plant height (cm) } \\
\hline & & & \multicolumn{2}{|c|}{ Seedling } & \multicolumn{2}{|c|}{ Maximum tillering stage } & \multicolumn{2}{|c|}{ Maturity stage } \\
\hline & F1 & F2 & $\mathbf{F 1}$ & F2 & F1 & F2 & F1 & F2 \\
\hline BRRI dhan 28 & $85 \mathrm{~b}$ & $90 \mathrm{a}$ & $21.2 \pm 1.6 \mathrm{a}$ & $20.2 \pm 1.3 \mathrm{a}$ & $55.3 \pm 4.8 \mathrm{a}$ & $73.7 \pm 6.2 \mathrm{a}$ & $108.7 \pm 10.2 \mathrm{ab}$ & $93.9 \pm 6.3 \mathrm{~b}$ \\
\hline BRRI dhan 67 & $90 \mathrm{a}$ & $90 \mathrm{a}$ & $27.3 \pm 1.3 \mathrm{a}$ & $29.6 \pm 1.2 \mathrm{a}$ & $50.6 \pm 5.5 \mathrm{ab}$ & $76.6 \pm 4.3 \mathrm{a}$ & $116.6 \pm 6.8 \mathrm{a}$ & $109.9 \pm 5.9 \mathrm{a}$ \\
\hline BRRI dhan 81 & $85 \mathrm{~b}$ & $90 \mathrm{a}$ & $23.4 \pm 1.5 \mathrm{a}$ & $22.4 \pm 1.9 \mathrm{a}$ & $46.6 \pm 3.7 \mathrm{~b}$ & $70.3 \pm 5.3 \mathrm{a}$ & $94.3 \pm 9.5 \mathrm{c}$ & $103.1 \pm 9.6 \mathrm{ab}$ \\
\hline BRRI dhan 84 & $80 \mathrm{c}$ & $80 \mathrm{~b}$ & $23.7 \pm 1.7 \mathrm{a}$ & $27.8 \pm 2.9 \mathrm{a}$ & $42.8 \pm 4.1 \mathrm{~b}$ & $60.4 \pm 6.8 \mathrm{ab}$ & $90.5 \pm 7.2 \mathrm{bc}$ & $122.9 \pm 11.3 \mathrm{a}$ \\
\hline BRRI dhan 86 & $85 \mathrm{~b}$ & $70 \mathrm{c}$ & $21.6 \pm 2.2 \mathrm{a}$ & $25.9 \pm 1.6 \mathrm{a}$ & $43.2 \pm 5.2 \mathrm{~b}$ & $76.4 \pm 6.1 \mathrm{ab}$ & $86.8 \pm 8.8 \mathrm{c}$ & $92.4 \pm 9.5 \mathrm{~b}$ \\
\hline
\end{tabular}

F1=Dumuria Field and F2= Batiaghata Field

Table 3. Growth contributing characters of rice varieties

\begin{tabular}{|c|c|c|c|c|c|c|c|c|c|c|}
\hline \multirow{3}{*}{ Rice Variety } & \multicolumn{4}{|c|}{ Number of tillers } & \multicolumn{4}{|c|}{ Spikelets per panicle } & \multirow{2}{*}{\multicolumn{2}{|c|}{ 1000-grain weight (gm) }} \\
\hline & \multicolumn{2}{|c|}{ Effective } & \multicolumn{2}{|c|}{ Total } & \multicolumn{2}{|c|}{ Filled } & \multicolumn{2}{|c|}{ Total } & & \\
\hline & F1 & F2 & F1 & F2 & F1 & F2 & F1 & F2 & F1 & F2 \\
\hline BRRI dhan 28 & $18 \pm 2 \mathrm{a}$ & $10 \pm 2 \mathrm{~b}$ & $19 \pm 2 \mathrm{a}$ & $11 \pm 2 \mathrm{~b}$ & $111 \pm 11 \mathrm{a}$ & $119 \pm 9 \mathrm{a}$ & $120 \pm 12 \mathrm{a}$ & $131 \pm 14 \mathrm{a}$ & $23.47 \pm 2.13 \mathrm{a}$ & $22.3 \pm 3.3 \mathrm{a}$ \\
\hline BRRI dhan67 & $20 \pm 2 \mathrm{a}$ & $14 \pm 3 \mathrm{a}$ & $23 \pm 2 \mathrm{a}$ & $16 \pm 2 \mathrm{a}$ & $110 \pm 9 \mathrm{a}$ & $123 \pm 8 \mathrm{a}$ & $115 \pm 9 \mathrm{a}$ & $128 \pm 11 \mathrm{a}$ & $22.47 \pm 3.1 \mathrm{a}$ & $22.2 \pm 2.6 \mathrm{a}$ \\
\hline BRRI dhan81 & $14 \pm 3 \mathrm{~b}$ & $11 \pm 2 \mathrm{~b}$ & $18 \pm 3 \mathrm{~b}$ & $15 \pm 3 \mathrm{a}$ & $76 \pm 6 \mathrm{~b}$ & $108 \pm 9 a b$ & $85 \pm 7 \mathrm{~b}$ & $113 \pm 12 \mathrm{ab}$ & $21.2 \pm 1.4 \mathrm{~b}$ & $22.4 \pm 3.26 \mathrm{c}$ \\
\hline BRRI dhan84 & $12 \pm 1 \mathrm{ab}$ & $14 \pm 1 \mathrm{a}$ & $16 \pm 1 \mathrm{~b}$ & $16 \pm 1 \mathrm{a}$ & $87 \pm 8 \mathrm{~b}$ & $82 \pm 6 \mathrm{~b}$ & $109 \pm 8 \mathrm{~b}$ & $112 \pm 8 \mathrm{ab}$ & $23.13 \pm 0.9 \mathrm{c}$ & $22.4 \pm 2.56 \mathrm{~b}$ \\
\hline BRRI dhan86 & $16 \pm 3 \mathrm{~b}$ & $13 \pm 1 \mathrm{a}$ & $19 \pm 3 a$ & $16 \pm 1 \mathrm{a}$ & $102 \pm 7$ a & $86 \pm 7 \mathrm{~b}$ & $117 \pm 8$ a & $103 \pm 9 \mathrm{~b}$ & $22.54 \pm 1.21 \mathrm{c}$ & $22.0 \pm 4.12 \mathrm{a}$ \\
\hline
\end{tabular}

F1=Dumuria Field and F2= Batiaghata Field

lands, about 1.056 million hectares are affected by varying degrees of salinity that usually covers $30 \%$ of cultivable land (2). Batiaghata Upazila is a subdistrict that is situated in the southwestern part of the country. The areas are covered by Kazibacha river that is seasonally flooded by this river. This causes various degrees of salinity in the soil. Mostly low-yielding, traditional rice varieties are grown during the wet season (2). Rice (Oryza sativa L.) is considered a salt-sensitive crop. Among the various factors limiting rice yield, salinity is one of the oldest and most serious environmental problems in the world (3). Rice yield components like grain yield are severely exaggerated by root-zone salinity. Primary branches per panicle, panicle length, spikelets per panicle, number of filled spikelets, and seed weight per panicle are significantly hampered by salinity (4). Negative impacts of salinity on seed germination and seedling growth as well as some physiological activities of cultivated plant species have been extensively investigated previously by various scientists $(5,6)$. BRRI dhan 28 is the most locally accepted rice varieties for its growth and yield response, but over the year this variety is losing its strength because of its susceptibility to neck blast disease and increasing of soil salinity in the south-west Bangladesh. That's why; new varieties have been tested to investigate the adaptability of the new varieties to replace BRRI dhan28 in the local environment. One of the important purposes of the present research is to generate information on the agronomic status (germination, growth and yield) and adaptability of newly released modern Boro rice varieties compared to the mega variety BRRI dhan28. This research will accelerate the vibrant information and varietal selection for rice cultivation and its performance in future of the investigated environment.

\section{Materials and Methods}

The experiment was conducted at two farmer's fields of Batiaghata and Dumuria Sub-district. Geographically, the experimental areas located at Rajbad, Batiaghata $\left(22^{\circ} 46^{\prime} \mathrm{N}\right.$ latitude and $89^{\circ} 31^{\prime} \mathrm{E}$ longitude at the elevation of above $5 \mathrm{~m}$ of sea level) and Koiya Bazar, Dumuria $\left(22^{\circ} 47^{\prime} \mathrm{N}\right.$ latitude and $89^{\circ} 29^{\prime} \mathrm{E}$ longitude at the elevation of above $7.7 \mathrm{~m}$ of sea level). In November to March, the weather is usually dry and the average temperature is 10 to $12^{\circ} \mathrm{C}$ with no to minimum precipitation rate. The soil of the experimental field was silty-loam having moderate saline to saline soil properties. Soil salinity was measured by Jeneway EC meter (1:2) at different stages of the rice plant as presented in Table 1. Different time EC was measured for observing whether there have any impacts of salinity on plant growth, yield and yield components. Salinity was increased as the field irrigated with more or less saline water over the time (Table 1). The experiment was carried out in two separate plots with a Randomized Complete Block Design (RCBD) where unit plot size was $4 \mathrm{~m} \times$ $5 \mathrm{~m}$. Each experiment was replicated in a thrice and the differences between the block was $1 \mathrm{~m}$ at all sites. A basal dose of triple super phosphate (TSP), muriate of potash (MP), gypsum and Zinc sulfate were used as the source of phosphorus, potassium, sulphur and Zinc applied at 22,75, 20 and $4 \mathrm{~kg} \mathrm{P,} \mathrm{K,} \mathrm{S} \mathrm{Zn} \mathrm{ha-1,} \mathrm{respectively.} \mathrm{Urea} \mathrm{was} \mathrm{top}$ 
Table 4. Yield contributing characters of rice varieties

\begin{tabular}{ccccccc}
\hline \multirow{2}{*}{ Rice Variety } & \multicolumn{2}{c}{ Grain yield (t/ha) } & \multicolumn{2}{c}{ Straw Yield (t/ha) } & \multicolumn{2}{c}{ Harvest Index (HI) (\%) } \\
\cline { 2 - 7 } & F1 & F2 & F1 & F2 & F1 & F2 \\
\hline BRRI dhan28 & $7.05 \pm 1.6 \mathrm{~b}$ & $7.14 \pm 1.9 \mathrm{~b}$ & $2.82 \pm 0.3 \mathrm{ab}$ & $2.35 \pm 0.29 \mathrm{ab}$ & $51.42 \pm 5.6 \mathrm{a}$ & $55.24 \pm 7.2 \mathrm{a}$ \\
\hline BRRI dhan67 & $7.29 \pm 1.1 \mathrm{a}$ & $7.89 \pm 1.23 \mathrm{a}$ & $2.98 \pm 0.2 \mathrm{a}$ & $2.51 \pm 0.32 \mathrm{a}$ & $51.02 \pm 4.2 \mathrm{a}$ & $57.84 \pm 8.6 \mathrm{a}$ \\
\hline BRRI dhan81 & $3.45 \pm 0.4 \mathrm{c}$ & $6.11 \pm 1.3 \mathrm{ab}$ & $3.17 \pm 0.4 \mathrm{a}$ & $1.83 \pm 0.26 \mathrm{c}$ & $52.08 \pm 2.3 \mathrm{~b}$ & $56.92 \pm 9.2 \mathrm{a}$ \\
\hline BRRI dhan84 & $3.74 \pm 0.8 \mathrm{c}$ & $7.16 \pm 2.3 \mathrm{~b}$ & $1.92 \pm 0.12 \mathrm{c}$ & $2.57 \pm 0.65 \mathrm{a}$ & $56.10 \pm 4.6 \mathrm{ab}$ & $53.58 \pm 5.4 \mathrm{~b}$ \\
\hline BRRI dhan86 & $5.26 \pm 1.2 \mathrm{bc}$ & $4.60 \pm 1.23 \mathrm{c}$ & $2.0 \pm 0.36 \mathrm{bc}$ & $2.34 \pm 0.8 \mathrm{ab}$ & $52.50 \pm 6.3 \mathrm{a}$ & $56.32 \pm 6.3 \mathrm{c}$ \\
\hline
\end{tabular}

F1=Dumuria Field and F2= Batiaghata Field

dressed as a source of nitrogen at $120 \mathrm{~kg} \mathrm{~N} \mathrm{ha}^{-1}$ in 3 equal splits (7). The Boro (dry season) crop is totally irrigated and the plots were irrigated as and when necessary. Five rice varieties BRRI dhan28 as a control, BRRI dhan67, BRRI dhan81, BRRI dhan84, BRRI dhan86 developed by the Bangladesh Rice Research Institute (BRRI) were used in the experiment. Seeds were sown in seedbed at farmer's field for the field trials and also some seeds were allowed for germination in petri dishes at room temperature. Forty-day old seedling was transplanted in puddled field at a designed block. Intercultural operations as well as irrigation were done as required. Uniform management practices were followed for all the varieties. Different growth data were taken at from germination to maturity stages. Grain yield and yield components data were determined at maturity. Grain yield was recorded from each plot and then converted to tons per hectare at $14 \%$ moisture. Data were analyzed following the Analysis of Variance (ANOVA) technique and mean differences were adjusted by the multiple comparison test (8) using the statistical computer based programme SPSS-16.

Table 1: Soil and water salinity at different stages of rice plant

\begin{tabular}{ccccc}
\hline \multirow{2}{*}{ Stages } & \multicolumn{2}{c}{ Soil Salinity (dS/m) } & \multicolumn{2}{c}{$\begin{array}{c}\text { Irrigation water } \\
\text { Salinity (dS/m) }\end{array}$} \\
\cline { 2 - 5 } & F1 & F2 & F1 & F2 \\
\hline $\begin{array}{c}\text { Initial sampling } \\
\text { before fertilizer } \\
\text { application }\end{array}$ & $3.29 \pm 0.7$ & $3.19 \pm 0.5$ & $2.42 \pm 0.9$ & $2.33 \pm 0.2$ \\
\hline Tillering & $3.5 \pm 0.9$ & $3.42 \pm 0.2$ & $2.6 \pm 0.9$ & $2.95 \pm 1.1$ \\
\hline Panicle initiation & $3.7 \pm 0.6$ & $3.9 \pm 0.8$ & $3.8 \pm 0.8$ & $3.7 \pm 0.6$ \\
\hline Milking & $4.7 \pm 0.8$ & $4.8 \pm 0.6$ & $4.2 \pm 0.7$ & $4.4 \pm 0.4$ \\
\hline
\end{tabular}

F1=Dumuria Field and F2= Batiaghata Field

\section{Results and Discussion}

Germination rate of different varieties is presented in Table 2. BRRI dhan67 showed the best result and significantly differed from others for Dumuria field whereas BRRI dhan67 and BRRI dhan 81 were insignificant with BRRI dhan28 but significant with other varieties in Batiaghata field. The lowest germination rate was observed at BRRI dhan 86 for Batiaghata field. This may due to seed germination rate was reduced by initial soil salinity due to the enzyme inhibition (9). High ion content in plant cells can persuade changes in protein hydration and their precipitation resulting in inhibition of enzyme activity (10). According to the Bangladesh Rice Research Institute (7), BRRI dhan67 can tolerate soil salinity up to $10 \mathrm{dS} / \mathrm{m}$ in its germination stages and other new verities are sensitive to salinity. The result supports the findings of the Bangladesh Rice Research Institute.

Genotype and interaction of genotype and environment had significant effect on plant height (Table 2). At initial tillering stage, all varieties showed insignificant differences among them but in the maximum tillering stage, BRRI dhan67 showed the significant difference among varieties but insignificant with BRRI dhan28. In maturity stage, BRRI dhan67 asserted the best result that was significant with BRRI dhan28 and other varieties in Dumuria and Batiaghata field. This may due to increasing soil salinity at matured stage. There are observations on the differences in plant height of rice varieties at different level of salinity (11). This result also supports another where high mortality rate of seedlings was found under saline field conditions (12). If an excessive amount of salt enters the plant, the concentration of salt eventually rises to a toxic level in older transpiring leaves causing premature senescence and reduces the photosynthetic leaf area of a plant to a level that cannot sustain growth (13). According to Bangladesh Rice Research Institute (7), BRRI dhan67 can tolerate up to $8 \mathrm{dS} / \mathrm{m}$ in its matured stage and $12-14 \mathrm{dS} / \mathrm{m}$ in its seedling stage up to 3 weeks whereas other new verities don't tolerate excessive soil salinity $(<3 \mathrm{dS} / \mathrm{m})$. The result supports the findings of Bangladesh Rice Research Institute.

Rice grain yields are highly reliant on the number of panicle-bearing tillers produced per plant. Different varieties showed the different tiller number according to Table 3. In terms of effective tiller and total tiller number, BRRI dhan67 showed the significant difference among other varieties except BRRI dhan28 for Dumuria field but in Batiaghata field, BRRI dhan67 showed the significant difference with BRRI dhan 28 and BRRI dhan81 but insignificant with other varieties. According to Bangladesh Rice Research Institute (7), BRRI dhan67 showed a tolerance to salinity stress. This result supports the study of Bangladesh 
Rice Research Institute (7). Reports are also there on variable tiller number due to varietal differences (14).

Table 3 also illustrates the grains per panicle and total spikelets per panicle that significantly varied among the varieties. BRRI dhan67 showed the best response in accordance with BRRI dhan28 that showed insignificant differences with each other. BRRI dhan84 responded comparatively poorer than that of other varieties. Salinity was found to be sharply decreased the filled grain per panicle (15). In an earlier study it was observed that filled grains per panicle correlated significantly with grain yield that supports the study (16).

Thousand grain weight was significantly affected the interaction of varieties and environments (Table 3). The highest 1000-grain weight was recorded in BRRI dhan28 $(23.47 \pm 2.13 \mathrm{gm}$ and $22.3 \pm 3.3 \mathrm{gm})$ that was insignificant with BRRI dhan67 but significant with other varieties. BRRI dhan67 had the finer grain than BRRI dhan28. The lowest value was found in BRRI dhan84 for Dumuria and BRRI dhan81 for Batiaghata. The highest 1000-grain weight of BRRI dhan28 was may be due to long and fine grain. Many scientists have found different 1000-grain weight for different varieties that support the study. Studies are also on 12 different rice varieties for observing the difference in thousand weights of grains due to morphological and varietal variation and found the differences that supports the study (17).

Interaction of variety and environments had significant effect on grain yield of the tested varieties (Table 4). Among five varieties, BRRI dhan67 yielded (7.04 t/ha) significantly higher than others. BRRI dhan28 was the second best yielder but it's statistically insignificant with BRRI dhan67. BRRI dhan81 was the poorest yielder for Dumuria field and BRRI Dhan86 was the poorest for Batiaghata field. More number of grains per panicle, less number of non-effective tillers and maximum tolerance of salinity stress of BRRI Dhan-67 resulted in higher yield. Poor tillering, less number of grains per panicle, lodging tendency, more straw yield and poor performance in salinity stress may be the reasons for such lower yield in BRRI dhan81 and BRRI dhan86. BRRI dhan81 and BRRI dhan84 showed poor results in Dumuria plot rather than Batiaghata plot due to susceptibility of more blast attack at matured stage and these two varieties highly affected by salinity. Differences in grain yield were also reported (18). The genotypes, which produced higher number of effective tillers per hill and higher number of grains per panicle also showed higher grain yield in rice (19). At matured stage, soil salinity increased thus reduced the yield growth for other varieties. Reduction in grain yield among varieties was reported due to salt stress $(20,21)$.
Straw yield also significantly affected by variety, environments and their interaction (Table 4). The highest straw weight was recorded in Dumuria for BRRI dhan81 (3.17t/ha) followed by BRRI dhan67 (2.98 t/ha). The lowest straw weight was observed in BRRI dhan84 (1.92 t/ha) followed by BRRI dhan86 (2 t/ha) and BRRI dhan28 (2.82 t/ha). In Batiaghata, the highest straw yield was found in BRRI dhan84 (2.57 t/ha) followed by BRRI dhan67 (2.51 t/ha) but they were statistically insignificant. Medium plant height, short duration and high yield can be the reason of low straw weight (22). Studies revealed that straw yield might be assigned to plant height and straw weight differed significantly due to varieties (14).

Harvest index (HI) is an important character that has physiological importance. It reflects translocation on alternatively dry matter partitioning of a given genotype to the economic parts. HI (\%) of different varieties is presented in Table 4. BRRI dhan67 showed the highest HI $(57.84 \pm 8.6) \%$ in Batiaghata filed. Though BRRI dhan28 HI $(51.42 \pm 5.6) \quad \%$ was the highest performer in Dumuria field but it showed the insignificant difference with BRRI dhan67 but was significant with other varieties. BRRI dhan 81 and BRRI dhan86 were the poorest HI consecutively Dumuria and Batiaghata field. There are reports on the contribution of high harvest index to yield (24). High yield is determined by the physiological process leading to a high net accumulation of photosynthates and their partitioning (25). Studies also revealed that variety has a significant influence on harvest index $(25,26)$.

\section{Conclusion}

Based on overall performances, BRRI dhan67 showed the highest potentiality among the tested varieties. BRRI dhan67 produced significantly highest grain yield followed by the highest value of the yield components compared to the check and other varieties. In compare with BRRI dhan28, maximum grain yield was obtained from BRRI dhan67 significantly $(p \leq 0.05)$. Considering all other parameters like effective and total tiller number along with germination rate, filled and total spikelets per panicle, plant height at different stages, 1000-grain weight, straw yield and harvest index, it can be asserted that BRRI dhan 67 would be the best modern rice varieties and could be the best choice as a new cultivars for environmental adaptation of rice in southwest Bangladesh.

\section{Competing Interest}

The authors declare that they have no competing interest. 


\section{Acknowledgements}

The authors thank to the Bill and Melinda Gates Foundation (BMGF) for financial support to conduct the field trial and the Adaptive Research Division of Bangladesh Rice Research Institute for experimental set up and data collection. All staff of Soil, Water and Environment discipline of Khulna University should be thanked for laboratory support.

\section{Authors' contribution}

TBS visited and supervised the experimental plots; wrote the manuscript. BK designed, executed the field trials, edited and improved the manuscript. TH worked as co-investigator and took care of the experiment throughout season and also data collection. MHR, ZM, MH helped in field and laboratory work.

\section{References}

1. Bangladesh: A Country Study: "Rice". Library of Congress, Washington, D.C. September 1988; Retrieved March 21, 2009.

2. Khatun M, Shuvo MAR, Salam MTB, Rahman SMH. Effect of organic amendments on soil salinity and the growth of maize (Zea mays L.). Plant Science Today 2019; 6(2): 106-11. https://doi.org/10.14719/pst.2019.6.2.49

3. McWilliam JR. The national and international drought and salinity effects on agricultural production. Aust. J. Plant Phsiol. 1986; 13: 1-13. https://doi.org/10.1071/PP9860001

4. Khatun S, Rizzo CA, Flowers TJ. Genotypic variation in the effect of salinity on fertility in rice. Plant Soil 1995; 173:239-50.

https://doi.org/10.1007/BF00011461

5. Ashraf MY, Khan MA, et al. Effect of salinity on seedling growth and solute accumulation in two wheat genotypes. Rachis 1991; 10: 30-31.

6. Khan AHM, Ashraf Y, et al. Growth ion and solute contents of sorghum grown under $\mathrm{NaCl}$ and $\mathrm{Na}_{2} \mathrm{SO}_{4}$ salinity stress. Acta Physiol. Plant 1995; 17: 261-68.

7. Bangladesh Rice Research Institute. Official webpage: www.brri.gov.bd

8. Gomez KA and Gomez AA. Statistical Procedures for Agricultural Research ( $2^{\text {nd }}$ edition) International Rice Research Institute, John Willey and Sons, Inc. Singapore1984; pp. 139-240.

9. Flowers TJ. Effect of sodium chloride on enzyme activity of four halophytic species of Chenopodiaceae. Phytochem 1972; 11: 1881-86. https://doi.org/10.1016/S0031-9422(00)90147-X

10. Waisel Y. Biology of halophytes. Academic Press, New York 1972; ISBN: 0127308504.

11. Islam MZ, Baset Mia MA, et al. Effect of different saline levels on growth and yield attributes of mutant rice. J. Soil. Nature 2007; 1(2): 18-22.

12. Ullah MA, Zaid SAR, et al. Effect of Planting Techniques (Direct seeding Vs. Transplanting) on Paddy Yield in Saltaffected Soil. Intl. J. Agric. Biol. 2007; 9(1): 179-80.
13. Munns R. Comparative physiology of salt and water stress. Plant Cell Environ. 2002; 25: 239-50. https://doi.org/10.1046/j.0016-8025.2001.00808.x

14. Sarkar SC. Performance of five selected hybrid rice varieties in aman season. M.S. Thesis, Dept of Agricultural Botany, Sher-e-Bangla Agricultural University, Dhaka 2014; Pp. 25-26, 44-46. Retrieved from http://archive.saulibrary.edu.bd:8080/bitstream/handle/1 23456789/342/Bot-SAU201401 12-08-02835.pdf? sequence $=1$

15. Zaman SK, Chowdhury DAM, et al. The effect of salinity on germination, growth, yield and mineral composition of rice. Bangladesh J. Agric. Sci. 1997; 24(1): 103-09.

16. Kiani G, Nematzadeh G. Correlation and path coefficient studies in F2 populations of rice. Notulae Scientia Biological 2012; $4(2)$ : $124-27$ https://doi.org/10.15835/nsb427366

17. Roy SK, Ali MY, Jahan MS, Saha UK, Ahmad-Hamdan MS, Hassan MM and Alam MM. Evaluation of growth and yield attributing characteristics of indigenous boro rice varieties. Life Sci. J. 2014; 11: 122-26.

18. Biswas JK, Hossain MA, Sarker BC, Hassan M and Haque MZ. Yield performance of several rice varieties seeded directly as late aman crops. Bangladesh J. Life Sci. 1998; 10: 47-52.

19. Dutta RK, Baset Mia MA and Khanam S. Plant architecture and growth characteristics of fine grain and aromatic rice and their relation with grain yield. Intl. Rice Comm. Newsletter 2002; 51: 51-56.

20. Zeng L, Shannon MC. Salinity effects on seedling growth and yield components of rice. Crop Sci. 2000; 40(4): 9961003. https://doi.org/10.2135/cropsci2000.404996x

21. Gain P, Mannan MA, Pal PS, Hossain MM and Pervin S. Effect of salinity on some yield attributes of rice. Pak. J. Biol. $\quad$ Sci. $2004 ; \quad 7(5)$ : 760-62. https://doi.org/10.3923/pjbs.2004.760.762

22. Hossain MZ. Performance of BRRI dhan 32 in the SRI and conventional methods and their technology Mixes. MS Thesis, Department of Agronomy, BAU, Mymensingh, 2002; pp. 28-71

23. Pheloung PC and Siddique KHM. Contribution of system dry matter to grain yield in wheat cultivars. Aust. J. Plant Physiol. 1991; 18(1): 53-64. https://doi.org/10.1071/PP9910053

24. Kusutani A, Tovata M, Asanuma K and Cui J. Studies on the varietal differences of harvest index and morphological characteristics of rice. Japanese J. Crop Sci. 2000; 69: 359-64. https://doi.org/10.1626/jcs.69.359

25. Miah MHN, Karim MA, Rahman MS and Islam MS. Performance of Nizersail mutants under different row spacing. Bangladesh J. Train and Dev. 1990; 3(2): 31-34.

26. Jisan MT, Paul SK and Salim M. Yield performance of some transplant Aman rice varieties as influenced by different levels of nitrogen. J. Bangladesh Agril. Univer. 2014; $\quad$ 12(2): 321-24. https://doi.org/10.3329/jbau.v12i2.28691

27. Tyeb A, Paul SK and Samad MA. Performance of variety and spacing on the yield and yield contributing characters of transplant Aman rice. J. Agrof. Environ. 2013; 7(1): 57-60. 